\title{
Nutritional status of hemodialysis patients with secondary hyperparathyroidism
}

L.T.T. Rezende ${ }^{1}$, L. Cuppari' ${ }^{1}$, A.B. Carvalho ${ }^{1}$, M.E.F. Canziani ${ }^{1}$, S.R. Manfredi', M. Cendoroglo ${ }^{1}$, D.M. Sigulem ${ }^{2}$ and S.A. Draibe ${ }^{1}$

\author{
${ }^{1}$ Disciplina de N efrologia, Departamento de Medicina, and \\ ${ }^{2}$ Departamento de Pediatria, Universidade Federal de São Paulo, \\ São Paulo, SP, Brasil
}

\section{Correspondence}

S.A. Draibe

Rua Borges Lagoa, 960

04038-002 São Paulo, SP

Brasil

Fax: +55-11-571-9039

E-mail: uremia@uol.com.br

Research supported by CAPES and O swaldo Ramos Foundation.

Publication supported by FAPESP.

Received August 19, 1999

Accepted July 25, 2000

\section{Abstract}

The repercussions of secondary hyperparathyroidism on the nutritional status of chronic renal failure patients have not been well established. Therefore, the aim of this study was to compare the nutritional indices of hemodialysis patients with and without secondary hyperparathyroidism. Sixteen hemodialysis patients with serum parathyroid hormone (PTH) levels higher than $420 \mathrm{pg} / \mathrm{ml}$ (hyperparathyroidism group) were matched for gender, age and length of dialysis treatment to 16 patients with serum PTH between 64 and $290 \mathrm{pg} / \mathrm{ml}$ (control group). The following parameters were assessed: anthropometric indices (body mass index, skinfold thickness, midarm muscle circumference and body fat), 4-day food diaries, protein catabolic rate, biochemical indices (blood urea nitrogen, serum creatinine, albumin, ionized calcium, inorganic phosphorus, serum alkaline phosphatase, $\mathrm{PTH}, \mathrm{pH}$ and $\mathrm{HCO}_{3}$ ) and dialysis efficiency. We did not observe differences in the anthropometric indices between the two groups. Only calcium intake was significantly different between groups (307.9 $\mathrm{mg}$ /day for the hyperparathyroidism group vs $475.8 \mathrm{mg}$ /day for the control group). Protein catabolic rate tended to be higher in the hyperparathyroidism group compared to the control group (1.3 vs 0.9 $\mathrm{g} \mathrm{kg}^{-1}$ day $\left.^{-1} ; \mathrm{P}=0.08\right)$. Except for blood urea nitrogen $(86.4 \mathrm{vs} 75.7 \mathrm{mg} /$ $\mathrm{dl}$ ), alkaline phosphatase (175 vs $65 \mathrm{U} / \mathrm{l})$ and PTH (898 vs $155 \mathrm{pg} / \mathrm{ml})$, no other differences were found between groups in the biochemical indices studied. PTH was directly correlated with protein catabolic rate $(\mathrm{r}=0.61 ; \mathrm{P}<0.05)$ and length of dialysis $(\mathrm{r}=0.53 ; \mathrm{P}<0.05)$ only in the hyperparathyroidism group. Considering the indices used, we could not demonstrate the deleterious effect of high PTH levels on the nutritional status of hemodialysis patients. Indirect evidence, however, suggests an action of PTH on protein metabolism.

\section{Introduction}

Malnutrition is present to some extent in approximately $40 \%$ of chronic renal failure (CRF) patients on maintenance hemodialysis $(1,2)$. Several markers of malnutrition such as low body mass index and low serum

\section{Key words}

- Nutritional assessment

- Parathormone

- Chronic renal failure

- Secondary

hyperparathyroidism 
acidosis (11), glucose intolerance (12), increased cytokine levels (13), and other hormonal derangements (14). Among these last disturbances, high parathyroid hormone (PTH) levels, frequently observed in CRF patients, may be implicated in the nutritional abnormalities found in these patients. In fact, it has been observed that patients with primary hyperparathyroidism may show evidence of weight loss, weakness and muscle atrophy and negative nitrogen balance (1517). It is not clear, however, to what extent these findings may be caused by either a direct deleterious effect of PTH on protein metabolism (18) or an indirect effect causing fatigue, anorexia, neuropsychiatric disturbances, myopathy or bone disease $(15,16)$.

Few studies have analyzed the effects of high PTH levels on protein metabolism. Experimental work on muscle tissue suggests that PTH induces an increase in protein catabolism (18), although this finding has not been confirmed by other investigators (19). Conversely, the effects of secondary hyperparathyroidism on the nutritional status of chronic hemodialysis patients have not been studied. Thus, the aim of this study was to compare the nutritional status of hemodialysis CRF patients with and without secondary hyperparathyroidism.

\section{Material and Methods}

\section{Patients}

The patients studied were selected from 189 patients dialyzed at the outpatient Dialysis Unit, Nephrology Division, Federal University of São Paulo (UNIFESP). Sixteen patients with secondary hyperparathyroidism on chronic hemodialysis were selected for this study. They were included in the study if they had serum PTH concentration higher than $420 \mathrm{pg} / \mathrm{ml}$ (hyperparathyroidism group; $\mathrm{N}=16$ ). They were matched for gender, age and length on dialysis to a group of patients with serum PTH concentration between 64 and $290 \mathrm{pg} / \mathrm{ml}$ (control group; $\mathrm{N}$ $=16$ ). According to some studies, normal bone metabolism in chronic renal failure has been associated with PTH levels up to 4 times the upper normal limit $(20,21)$. None of the patients in the control group had ever been treated for secondary hyperparathyroidism. Exclusion criteria for both groups were age lower than 18 years, diabetes mellitus, autoimmune, malignant or infectious diseases, chronic alcoholism, patients submitted to parathyroidectomy or to immobilization, and those with kidney transplantation failure in the last 6 months. All subjects were instructed to eat approximately 30 to

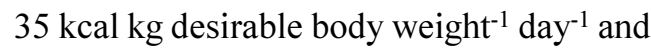

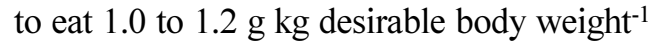
day $^{-1}$ of protein. All patients studied were dialyzed 3 times a week for $4 \mathrm{~h}$ with a Cuprophan ${ }^{\circledR}$ membrane.

The study was approved by the Ethics Committee of UNIFESP and informed consent was obtained from each subject.

\section{Study protocol}

After selection, we first interviewed the patients in order to obtain informed consent, to collect blood samples for biochemical analysis and to instruct them to fill out the food diaries. Anthropometric data and the food diaries were obtained one week later and after a regular hemodialysis session.

\section{Nutritional assessment}

Anthropometric measurements included body weight, height, tricipital skinfold (TSF), biceps, subscapular and suprailiac skinfold thickness, and midarm muscle circumference (MAMC). Body mass index (BMI) was calculated as body weight divided by squared height (22). Skinfold thicknesses were measured using Lange calipers (Cambridge Instrument, Cambridge, MD, USA). These measurements were performed by the same observer on the side of the body opposite to 
that of the vascular access for hemodialysis. Percentage of fat was estimated from the sum of four skinfold thicknesses according to the equations of Durnin and Wormersley (23). MAMC was calculated using the formula (24): MAMC = arm circumference (0.314 x TSF). Percent standard TSF and MAMC were obtained using the National Health and Nutrition Examination Survey (NHANES) percentile distribution tables adapted by Frisancho (24). Dietary intake was evaluated from 4-day food diaries that included 1 dialysis day, 2 days without the treatment and 1 weekend day. Energy and protein intakes were expressed in relation to desirable body weight. Energy and nutrients were calculated using a computer software developed at UNIFESP which contains the US Department of Agriculture tables as the nutrient data base (25). Protein catabolic rate was determined according to the formula of Sargent and Gotch (26).

\section{Biochemical parameters}

Blood samples were drawn from the patients under fasting conditions immediately before the dialysis session for determination of ionized calcium, phosphorus, alkaline phosphatase, $\mathrm{PTH}, \mathrm{pH}$, bicarbonate, albumin, urea nitrogen, and serum creatinine. Phosphorus, creatinine and urea nitrogen were determined with a standard autoanalyzer. Ionized calcium was determined using a calcium-specific electrode (AVL 9140, Medical Instruments AG, Schaffhausen, Switzerland; normal range $=1.12$ to 1.32 $\mathrm{mmol} / \mathrm{l})$. Total alkaline phosphatase was determined using a commercial enzyme linked immunoassay kit (ELISA; normal values range from 40 to $190 \mathrm{U} / 1)$. PTH was determined using an immunofluorimetric assay which detects the intact PTH molecule with normal values ranging from 10 to $70 \mathrm{pg} / \mathrm{ml}$ (27). Bicarbonate and $\mathrm{pH}$ were measured using a specific electrode (normal value range $=24$ to $28 \mathrm{mEq} / 1$ and 7.32 to 7.42 , respec- tively). The colorimetric method was used to determine serum albumin. Hemodialysis efficiency was assessed by calculating $\mathrm{Kt} / \mathrm{V}$ (28).

\section{Statistical analysis}

All data are expressed as median and range. The Mann-Whitney U-test was used to compare patients with and without secondary hyperparathyroidism. The Spearman rank correlation coefficient was calculated to test quantitative associations between two variables. The Fisher test was used do compare the frequency of malnutrition between the two groups. Statistical significance was defined as $\mathrm{P}<0.05$.

\section{Results}

The clinical and biochemical characteristics of the patients are shown in Table 1. There was a predominance of males and the patients were relatively young. The median length of dialysis was relatively short. In-

Table 1 - Clinical and biochemical characterization of the patients.

Data are reported as median and range (in parentheses). $\mathrm{H}=$ Hypertension, $\mathrm{CG}=$ chronic glomerulonephritis, PKD = polycystic kidney disease, BUN = blood urea nitrogen, $\mathrm{PTH}=$ parathyroid hormone, $\mathrm{ND}=$ not determined. ${ }^{*} \mathrm{P}<0.05$ vs control group (Mann-Whitney U-test).

\begin{tabular}{lll}
\hline & $\begin{array}{c}\text { Hyperparathyroidism } \\
\text { group }(\mathrm{N}=16)\end{array}$ & \multicolumn{1}{c}{$\begin{array}{c}\text { Control } \\
\text { group (N=16) }\end{array}$} \\
\hline Gender (male/female) & $10 / 6$ & $10 / 6$ \\
Age (years) & $46.5(20-80)$ & $47.0(20-81)$ \\
Length of dialysis (months) & $17.5(7-289)$ & $21.5(12-132)$ \\
Etiology & $\mathrm{H}=4, \mathrm{CG}=4, \mathrm{PKD}=2$ & $\mathrm{H}=9, \mathrm{CG}=2$ \\
& $\mathrm{ND}=5, \mathrm{Others}=1$ & Others $=5$ \\
BUN (mg/dl) & $86.4(60.2-110.2)$ & $75.7(50.4-110.2)^{*}$ \\
Serum creatinine (mg/dl) & $13.5(6.8-17.0)$ & $13.6(6.5-16.3)$ \\
Dialysis efficiency (Kt/N) & $1.4(0.4-1.7)$ & $1.2(0.8-1.6)$ \\
pH & $7.20(7.10-7.30)$ & $7.25(7.10-7.40)$ \\
Serum bicarbonate (mEg/l) & $17.1(11.7-28.7)$ & $17.3(13.5-26.2)$ \\
Serum albumin (g/dl) & $4.2(3.3-5.3)$ & $4.0(3.4-4.9)$ \\
Serum ionized calcium (mmol/l) & $1.20(1.10-1.60)$ & $1.20(1.10-1.30)$ \\
Serum inorganic phosphorus (mg/dl) & $5.5(1.7-9.1)$ & $6.0(1.7-9.5)$ \\
Serum alkaline phosphatase (U/l) & $175.0(51.0-1095.0)$ & $65.0(31.0-215.0)^{*}$ \\
Serum PTH (pg/ml) & $898.0(439.0-2120.0)$ & $155.0(64.0-288.0)^{*}$
\end{tabular}


deed, $25 \%$ of the patients in the hyperparathyroidism group and $19 \%$ of the patients in the control group had been on chronic hemodialysis for less than 12 months. Patients with hyperparathyroidism had significantly higher levels of blood urea nitrogen (BUN) as compared with the control group. Both groups had metabolic acidosis. In fact, 9 patients $(56 \%)$ in the hyperparathyroidism group and $8(50 \%)$ in the control group had venous blood $\mathrm{pH}$ below 7.32. The median serum albumin levels were within the normal range in both groups and only one patient in each group had a serum albumin level of less than $3.5 \mathrm{~g} / \mathrm{dl}$. The $\mathrm{Kt} / \mathrm{V}$ values were similar and adequate in both groups of patients. Median ionized calcium value was normal, with only one patient presenting hypercalcemia $\left(\mathrm{iCa}^{2+}=1.60 \mathrm{mmol} / \mathrm{l}\right)$. Eleven patients $(69 \%)$ in each group showed serum phosphorus levels higher than $4.5 \mathrm{mg} / \mathrm{dl}$. As expected, PTH values were significantly higher in the hyperparathyroidism group.

As can be seen in Table 2, we did not find any significant difference in the anthropometric indices between groups. Twelve patients $(75 \%)$ with secondary hyperparathyroidism and 10 patients $(62.5 \%)$ in the control group had BMI between 18.5 and 25.0 $\mathrm{kg} / \mathrm{m}^{2}$. The median standard percent of TSF was 76.7 and $77.1 \%$, respectively. Only 3 patients $(18.8 \%)$ with secondary hyperparathyroidism and $1(6.2 \%)$ in the control group showed signs of malnutrition with TSF values below the 5 th percentile. These frequencies were not different between groups. The median percent standard values of the MAMC were $92.0 \%$ in the hyperparathyroidism group and $89.5 \%$ in the control group. However, 5 patients $(31.3 \%)$ with secondary hyperparathyroidism and 6 patients (37.5\%) in the control group showed MAMC values below the 5 th percentile. Considering both parameters (TSF and MAMC), only 2 patients in the hyperparathyroidism group and 1 patient in the control group had values below the 5 th percentile.
Table 2 - Anthropometric indices.

Data are reported as median and range (in parentheses). BMI = Body mass index, TSF $=$ tricipital skinfold thickness, MAMC = midarm muscle circumference, $\mathrm{LBM}=$ lean body mass.

\begin{tabular}{lcc}
\hline & Hyperparathyroidism group $(\mathrm{N}=16)$ & Control group $(\mathrm{N}=16)$ \\
\hline Body weight $(\mathrm{kg})$ & $61.4(50.0-81.1)$ & $63.1(50.0-78.6)$ \\
BMI $\left(\mathrm{kg} / \mathrm{m}^{2}\right)$ & $24.0(18.6-30.7)$ & $22.1(18.9-30.6)$ \\
TSF (standard \%) & $76.7(41.7-136.4)$ & $77.1(37.5-167.0)$ \\
MAMC (standard \%) & $92.0(70.0-115.4)$ & $89.5(68.4-122.0)$ \\
Body fat (\%) & $24.7(11.2-40.0)$ & $22.0(9.8-37.7)$ \\
LBM $(\mathrm{kg})$ & $46.8(36.4-60.2)$ & $49.9(34.0-64.0)$
\end{tabular}

Table 3 - Dietary intake and protein catabolic rate.

Data are reported as median and range (in parentheses). ${ }^{+} \mathrm{N}=12 .{ }^{*} \mathrm{P}<0.05$ vs control group (Mann-Whitney U-test).

\begin{tabular}{lll}
\hline & Hyperparathyroidism group $(\mathrm{N}=16)$ & Control group $(\mathrm{N}=16)$ \\
\hline Energy $\left(\mathrm{kcal} \mathrm{kg}^{-1}\right.$ day $\left.^{-1}\right)$ & $25.4(12.9-59.5)$ & $23.3(20.0-61.6)$ \\
Protein $\left(\mathrm{g} \mathrm{kg}^{-1}\right.$ day $\left.^{-1}\right)$ & $0.95(0.5-2.3)$ & $0.90(0.6-2.8)$ \\
Calcium $(\mathrm{mg} / \mathrm{day})$ & $307.9(109.8-1280.0)$ & $475.8(226.8-1300.4)^{*}$ \\
Phosphorus $(\mathrm{mg} / \mathrm{day})$ & $639.7(387.7-2206.4)$ & $816.4(426.3-1724.8)$ \\
Protein catabolic rate & $1.3(0.7-1.9)$ & $0.90(0.5-1.8)$ \\
$\left(\mathrm{g} \mathrm{kg}^{-1} \text { day }^{-1}\right)^{+}$ & &
\end{tabular}

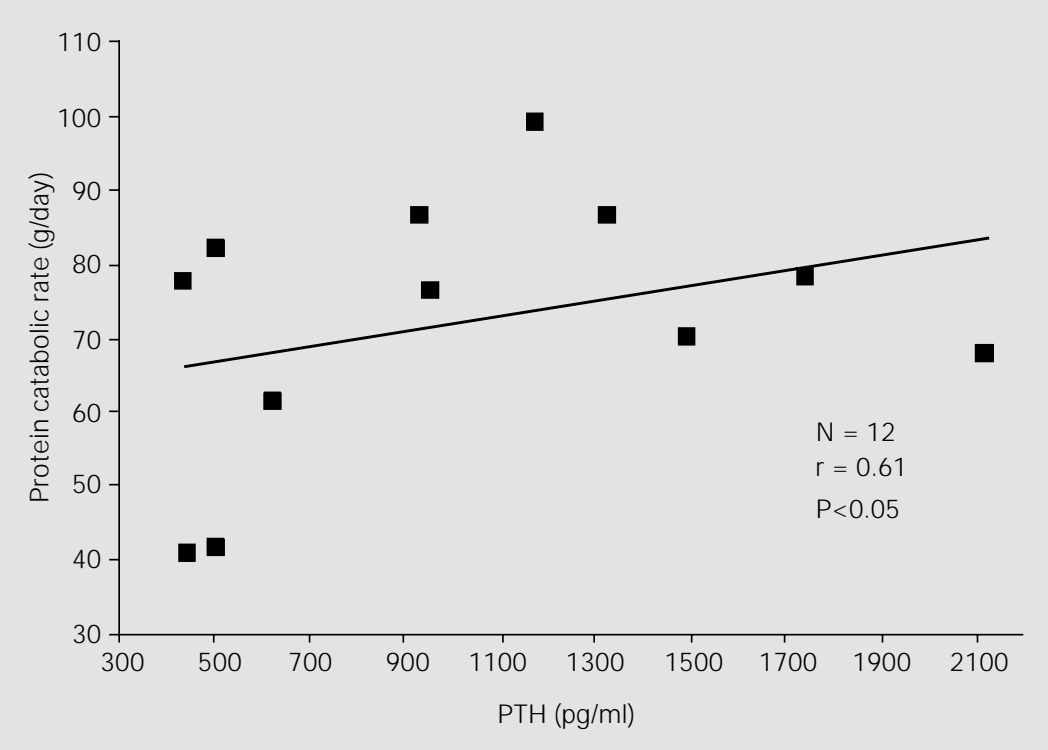

Figure 1 - Protein catabolic rate versus parathyroid hormone (PTH) in the hyperparathyroidism group. 
The analysis of the food diaries showed that the median energy and protein intakes were below the recommendations and were similar in both groups, averaging 23 to 25 $\mathrm{kcal} \mathrm{kg}^{-1} \mathrm{day}^{-1}$ (Table 3), but calcium intake was significantly lower in the hyperparathyroidism group. There was a trend to a higher phosphorus intake in the patients in the control group; protein catabolic rate was higher in patients in the hyperparathyroidism group but the difference did not reach statistical significance $\left(1.3\right.$ vs $0.9 \mathrm{~g} \mathrm{~kg}^{-1}$ day $^{-1} ; \mathrm{P}=$ 0.08). No correlations were found between PTH values and anthropometric indices in the population as a whole or in the hyperparathyroidism group. However, in the latter group PTH was significantly correlated with protein catabolic rate $(\mathrm{N}=12 ; \mathrm{r}=0.61$; $\mathrm{P}<0.05$; Figure 1). Furthermore, $\mathrm{PTH}$ levels were correlated with length of dialysis $(\mathrm{N}=$ $16 ; \mathrm{r}=0.53 ; \mathrm{P}<0.05)$ only in the hyperparathyroidism group.

\section{Discussion}

In the present study we tested the hypothesis that high PTH levels could have deleterious effects on the nutritional status of patients with secondary hyperparathyroidism. However, when comparing the hyperparathyroidism patients to their respective controls, we did not observe any significant difference in any of the nutritional indices studied. In fact, although they were matched only for age, gender and length of dialysis, both groups of patients showed similar values of BMI, TSF, MAMC, body fat, lean body mass and serum albumin.

The energy intake of our patients, of 23 to $25 \mathrm{kcal} \mathrm{kg}^{-1} \mathrm{day}^{-1}$, was far below the recommended amount for patients on hemodialysis (29), as systematically observed in many studies $(1,6,7)$. Anorexia of chronic renal failure may be implicated in this low energy intake and may be related to the malnutrition of these patients (30). It is worthy of note that, even with low energy consumption, only 2 patients in the hyperparathyroidism group and 1 patient in the control group were considered malnourished. Probably, in both groups the deleterious effects of such a low energy intake on nutritional status was not observed because most of the patients had been on dialysis for a short period of time. In fact, the hemodialysis procedure may cause malnutrition either by inducing losses of nutrients or by promoting inflammatory responses through blood-membrane interactions $(8,9)$. Another possibility is underreporting and/or systematic errors in the estimation of food consumption by the patients as observed by some authors (31).

PTH has long been considered a uremic toxin, with many deleterious cellular and metabolic effects (32). It increases bone turnover (33) and induces neuropathy (34), myopathy $(15,16)$, cardiac hypertrophy $(35)$, hyperlipidemia (36), carbohydrate intolerance (12) and immune dysfunction (37). Although specific studies are lacking, such conditions could influence the nutritional status of uremic patients with secondary hyperparathyroidism. Garber(18) demonstrated in vitro that high $\mathrm{PTH}$ levels enhanced muscle proteolysis and increased the release of alanine and glutamine. This effect, however, was observed only in normal rats. On the other hand, Wassner and Li (19) did not observe any change in protein metabolism when muscle of normal rats was perfused with PTH. In humans, it was observed that patients with primary hyperparathyroidism have a negative nitrogen balance that is corrected after parathyroidectomy (17). In the present study, according to the anthropometric indices, we did not observe any interference of secondary hyperparathyroidism with the nutritional status of the patients. However, there was some indirect evidence suggesting that PTH could have exerted its action causing some degree of protein catabolism. In fact, BUN was significantly higher and protein catabolic rate tended to be more elevated in patients with hyperparathyroid- 
ism, despite the similar protein intake observed in both groups. Moreover, PTH was directly correlated with protein catabolic rate in the hyperparathyroidism group, suggesting an action of PTH in increasing protein catabolism. On the other hand, we must consider that this indirect evidence of protein catabolism (high BUN and protein catabolic rate values) could also be the result of a higher protein intake in the hyperparathyroidism group which, however, was not detected in the food diaries. If that effect did occur, the anthropometric indices used to estimate the muscle mass of these patients may have not been sensitive enough to detect such interference. Alternatively, it is also possible that the duration of secondary hyperparathyroidism was too short to adversely affect muscle mass as these patients had been on dialysis for a relatively short period of time. Accordingly, PTH was significantly correlated with the length of dialysis treatment in the patients with hyperparathyroidism.

Finally, despite the reasonable strength of this study protocol, the number of patients studied does not permit the characterization of a definite effect of secondary hyperparathyroidism on the nutritional status of hemodialysis patients. Furthermore, as indicated by the relationship between time on dialysis and degree of hyperparathyroidism, a study protocol including the duration of hyperparathyroidism would better analyze its influence on nutritional status. Since there was indirect evidence that PTH could interfere with protein catabolism, other studies are necessary to elucidate this interaction.

\section{References}

1. Bergström J \& Lindholm B (1993). Nutrition and adequacy of dialysis: How do hemodialysis and CAPD compare? Kidney International, 43 (Suppl 40): 39-50.

2. Cuppari L, Medeiros FAM, Pappini HF, Cendorolo Neto M, Canziani MEF, Martini L, Ajzen H \& Draibe SA (1994). Effectiveness of oral energy-protein supplementation in severely malnourished hemodialysis patients. J ournal of Renal Nutrition, 4 (Suppl 3): 127-135.

3. Degoulet $P$, Reach $L$, Aimé $F$, Rioux $P$, J acobs C \& Legrain M (1980). Risk factors in chronic hemodialysis. Proceedings of the European Dialysis and Transplant Association, 17: 149-154.

4. Lowrie EG \& Lew NL (1990). Death risk in hemodialysis patients: the predictive values of commonly measured variables and an evaluation of death rate differences between facilities. American J ournal of Kidney Diseases, 15 (Suppl 5): 458-482.

5. Acchiardo SR, Moore LW \& Latour PA (1983). Malnutrition as the main factor in morbidity and mortality of hemodialysis patients. Kidney International, 24 (Suppl 16): 199-203.

6. Cuppari L, Draibe AS, Anção MS, Sigulem $D$, Sustovic DR, Ajzen $\mathrm{H} \&$ Ramos OL (1989). Avaliação nutricional de pacientes renais crônicos em programa de hemodiálise. Estudo multicêntrico. Revista da
Associação Médica Brasileira, 35 (Suppl 1): 9-14.

7. Shoenfeld $P$, Henry RR, Laird NM \& Roxe DM (1983). Assessment of nutritional status of the national cooperative dialysis study population. Kidney International, 23 (Suppl 13): 80-88.

8. Kopple J D, Swendseid ME, Shinaberger J H \& Umezawa CY (1973). The free and bound amino acids removed by hemodialysis. Transactions of the American Society for Artificial Internal Organs, 19: 309313.

9. Gutierrez A, Alvestrand A, Wahren J \& Bergstrom J (1990). Effect of in vivo contact between blood and dialysis membranes on protein catabolism in humans. Kidney International, 38: 487-494.

10. Bergström J (1995). Why are dialysis patients malnourished? American J ournal of Kidney Diseases, 26 (Suppl 1): 229-241.

11. Mitch WE, Medina R, Grieber S, May RC, England BK, Price SR, Bailey J L \& Goldberg AL (1994). Metabolic acidosis stimulates muscle protein degradation by activating the adenosine triphosphate-dependent pathway involving ubiquitin and proteasomes. J ournal of Clinical Investigation, 93: 2127-2133.

12. Akmal M, Massry SG, Goldstein DA, Fanti P, Weisz A \& DeFronzo RA (1985). Role of parathyroid hormone in the glucose intol- erance of chronic renal failure. J ournal of Clinical Investigation, 75: 1037-1044.

13. Luger A, Kovarik J \& Stummvoll HK (1987). Blood-membrane interaction in hemodialysis leads to increased cytokine production. Kidney International, 32: 8488.

14. Eknoyan $\mathrm{G}$ (1988). Effects of renal insufficiency on nutrient metabolism and endocrine function. In: Mitch WE \& Klahr S (Editors), Nutrition and the Kidney. Little Brown and Company, Boston/Toronto, 2958.

15. Frame B, Heinze J $r$ EG, Block MA \& Manson GA (1968). Myopathy in primary hyperparathyroidism. Annals of Internal Medicine, 68: 1022-1027.

16. Patten BM, Bilezikian JP, Mallete LE, Prince A, Engel WK \& Aurbach GH (1974). Neuromuscular disease in primary hyperparathyroidism. Annals of Internal Medicine, 80: 182-193.

17. Kopple J D, Cianciaruso B \& Massry SG (1980). Does parathyroid hormone cause protein wasting? Contributions to Nephrology, 20: 138-148.

18. Garber AJ (1983). Effect of parathyroid hormone on skeletal muscle protein and amino acid metabolism in the rat. J ournal of Clinical Investigation, 71: 1806-1821.

19. Wassner SJ \& Li J B (1987). Lack of an acute effect of parathyroid hormone 
within skeletal muscle. International J ournal of Pediatric Nephrology, 8: 15-20.

20. Quarles DL, Lobaugh B \& Murphy G (1992). Intact parathyroid hormone overestimates the presence and severity of parathyroid-mediated osseous abnormalities in uremia. J ournal of Clinical Endocrinology and Metabolism, 75: 145-150.

21. Torres A, Lorenzo V, Hernández D, Rodríguez J C, Concéption MT, Rodríguez AP, Hernandez A, De Bonis E, Darias E, Gonzáles-Posada J M, Losada M, Rufino M, Felsenfeld AJ \& Rodríguez M (1995). Bone disease in predialysis, hemodialysis, and CAPD patients: Evidence of a better bone response to PTH. Kidney International, 47: 1434-1442.

22. Keys A, Fidanza F \& Kcarvonen MJ (1972). Indices of relative weight and obesity. J ournal of Chronic Diseases, 25: 329-343.

23. Durnin JV \& Wormersley J (1974). Body fat assessed from total body density and its estimation from skinfold thickness: measurements on 481 men and women aged from 16 to 72 years. British J oumal of Nutrition, 32: 77-97.

24. Frisancho AR (1981). New norms of upper limb fat and muscle areas for assessment of nutritional status. American J ournal of Clinical Nutrition, 34: 2540-2545.

25. United States of America. Department of Agriculture (1963). Human Nutrition Information Service: Composition of Foods.
Raw, Processed, Prepared. Agriculture Handbook No. 8, Series 1-16. Revised 1976-1986.

26. Sargent J A \& Gotch AS (1979). Mass balance: a quantitative guide to clinical nutritional therapy. J oumal of the American Dietetic Association, 75: 547-555.

27. Vieira J G, Kasamatsu TS, Amarante EC \& Kunii IS (1994). Development and clinical application of an immunofluorometric assay for intact parathyroid hormone. Brazilian J ournal of Medical and Biological Research, 27: 2379-2382.

28. J indal KK, Manuel A \& Goldstein MB (1989). Percent reduction in blood urea concentration during hemodialysis (PRU): a simple and accurate method to estimate $\mathrm{Kt} / \mathrm{N}$ urea. Transactions of the American Society for Artificial Internal Organs, 12: 411-419.

29. Slomowitz LA, Monteon FJ, Grosvenor M, Laidlaw AS \& Kopple J D (1989). Effect of energy intake on nutritional status in maintenance hemodialysis patients. Kidney International, 35: 704-711.

30. Ikizler TA, Greene J , Wingard RT, Parker PA \& Hakin RM (1995). Spontaneous dietary protein intake during progression of chronic renal failure. J ournal of the American Society of Nephrology, 6: 1386-1391.

31. Basiotis PP, Welsh SO \& Cronin FJ (1987). Number of days of food intake records required to estimate individual and group nutrient intakes with defined confidence. J ournal of Nutrition, 117 (Suppl 9): 16381641.

32. Feinfeld DA (1992). The role of parathyroid hormone as a uremic toxin: current concepts. Seminars in Dialysis, 5 (Suppl 1): 48-53.

33. Kronemberg HM (1993). Parathyroid hormone: mechanism of action. In: Favus MJ (Editor), Primer on the Metabolic Bone Diseases and Disorders of Mineral Metabolism. Lippincott-Raven, Philadelphia, 58-60.

34. Goldstein DA, Chui LA \& Massry SG (1978). Effect of parathyroid hormone and uremia on peripheral nerve calcium and motor nerve conduction velocity. J ournal of Clinical Investigation, 62: 88-93.

35. Schluter KD \& Piper HM (1998). Cardiovascular actions of parathyroid hormone and parathyroid hormone-related peptide. Cardiovascular Research, 37 (Suppl 1): 3441.

36. Smogorzewiski M, Piskorska G, Borum PR \& Massry SG (1988). Chronic renal failure, parathyroid hormone and fatty acids oxidation in skeletal muscle. Kidney International, 33: 555-560.

37. Vanholder R, Van Biessen W \& Ringoir S (1993). Contributing factors to the inhibition of phagocytosis in hemodialyzed patients. Kidney International, 44: 208-214. 